\title{
Predatory Behavior of Leucauge magnifica
}

\section{(Araneae: Tetragnathidae)}

\author{
Makoto Yoshida \\ Department of Biotechnology, Faculty of Science and Engineering, Ritsumeikan University, \\ Kusatsu, Shiga, 525-8577 Japan
}

\begin{abstract}
The predatory behavior of Leucauge magnifica was studied. This species employed five predatory sequences: seize-pull out, bite-pull out, bite-wrap, wrap-bite, and wrap. Attack wrapping was used to subdue various types of prey such as grasshoppers, damselflies, ants and stinkbugs, which may be large and/or dangerous prey. Furthermore, living ants were more frequently immobilized by wrapping than dead ants. It suggests that attack wrapping is an effective method to immobilize large and/or dangerous prey.
\end{abstract}

Key words - predatory behavior, attack wrapping, Leucauge magnifica, Tetragnathidae

Web-building spiders attack their prey trapped in the webs by biting with the jaws or by wrapping with swathes of silks in order to immobilize them (Eberhard 1967; Robinson et al. 1969). Eberhard (1967) stated that web spiders in the primitive stage of the evolution of predatory behavior immobilized their prey exclusively by biting, however, web-building spiders in the advanced stage used both biting and wrapping to immobilize their prey. Robinson et al. (1969) agreed with Eberhard (1967), and stated that there were several stages of the evolution of predatory behavior in Araneidae, judging from mainly whether or not attack wrapping was used.

Robinson et al. (1969) studied the predatory behavior of Nephila clavipes, and it was the first study on the predatory behavior of tetragnathid species. The study on Nephila clavipes (Robinson et al. 1969; Robinson \& Mirick 1971) and N. maculata (Robinson \& Robinson 1973) showed that Nephila immobilized its prey exclusively by biting. Thereafter, though Eberhard (1982) stated briefly that Dolicognatha spp., Leucauge spp., and Chrysometa spp. used attack wrapping against some types of the prey, the predatory behavior of tetragnahtid spiders has mainly been studied by me (Yoshida 1987, 1989, 1990; Yoshida \& Shinkai 1993). Yoshida (1989) showed that Metleucauge (M. kompirensis, M. yunohamensis and M. yaginumai) immobilized their prey exclusively by biting. On the other hand, Tetragnatha (T. praedonia) and Meta (M. reticuloides and $M$. japonica) used attack wrapping against some types of the prey (Yoshida 1987, 1990; Yoshida \& Shinkai 1993).

In this paper, I report the predatory behavior of Leucauge magnifica Yaginuma, and discuss the diversity of the predatory behavior in Tetragnathidae in relation to the conditions of silk glands.

Mr. Akira Shinkai read this manuscript and gave me beneficial comments. I wish to express my sincere thanks to him.

\section{Materials and Methods}

The investigation was done in 1990 and 1992 at small valleys in Kyoto City, central Honshu. I observed the predatory behavior of adult females of Leucauge magnifica both with natural prey and with the fairly large prey given by me. The observation was done 
less than twice per a spider per several days in order to avoid the satiation of spiders.

\section{Results}

\section{1) Predatory sequences}

Following five predatory sequences (seize-pull out, bite-pull out, bite-wrap, wrapbite and wrap) were observed.

a) Seize-pull out (SP): Spiders ran to the prey, seized it in the jaws and pulled it out of the web. Spiders then carried the prey in the jaws to the hub. In most cases, spiders returned to the hub by dropping from the web, hanging with the dragline attached to the hub, and then climbed quickly to the hub along the dragline ("drop and climb up" behavior).

b) Bite-pull out (BP): This sequence resembles SP, but it includes the behavior unit "biting". Spiders usually bit some part of the prey for fairly long time (several seconds to a few minutes). Then the spider pulled it from the web with the jaws. The prey insects were carried either by "drop and climb up" or by walking along a radial silk.

c) Bite-wrap (BW): Prey insects were immobilized by biting. After immobilization biting, spiders first wrapped the prey with silk usually while it was still in the jaws. Then they were wrapped further after releasing it from the jaws. Spiders cut out all the entangling silk lines, in order to remove the prey from the web. In most cases, the prey insects were carried to the hub, being suspended on a silk line.

d) Wrap-bite (WB): The prey insects were immobilized by wrapping with silks. Spiders bent their abdomen, threw swathes of silks ahead to the prey at a distance. Then they bit the prey for fairly long time. Spiders then wrapped the prey with silk usually while it was still in the jaws. After that, they were wrapped further after releasing it from the jaws. Spiders cut out all the entangling silk lines, in order to remove the prey from the web. In most cases, the prey insects were carried to the hub, being suspended on a silk line.

e) Wrap (W): The prey insects were immobilized by wrapping with silks. But, spiders did not bite them after wrapping. Spiders cut out all the entangling silk lines, in order to remove the prey from the web. In most cases, the prey insects were carried to the hub, being suspended on a silk line.

\section{2) Frequencies of predatory sequences}

Table 1 shows the frequencies of predatory sequences to various taxa of prey. In total, $66.0 \%$ of the prey were successfully captured by spiders. All the individuals were captured in the following taxa: leafhoppers (two individuals), winged ants (three individuals), lepidopteran larvae (two individuals), Ephemeroptera (three individuals) and Neuroptera (one individual). Diptera and Odonata were also captured at high frequency $(85.7 \%$ and $80.0 \%$, respectively). On the contrary, Orthoptera and "bees \& wasps" were captured at low frequency (34.5\% and $40.0 \%$, respectively).

In the successful captures, WB (Wrap-bite) was most frequently used (40.9\%) and BW (Bite-wrap) was next frequently used (32.3\%). Frequencies of other sequences were low. Wrapping was more frequently used than biting to immobilize the prey $(54.3 \% \mathrm{vs}$ 45.7\%). Following taxa were immobilized exclusively or mainly by biting: Lepidoptera, Ephemeroptera, bees and wasps, Neuroptera and Diptera. All the individuals were immobilized by biting in Lepidoptera (17 individuals), Ephemeroptera (three individuals), bees \& wasps (two individuals) and Neuroptera (one inidividual). Diptera were also immobilized mainly by biting (90\%). On the contrary, following taxa were im- 
Table 1. Frequencies of attack sequences employed by Leucauge magnifica. Numerals show the numbers of prey insects. Numerals in parentheses show the percentages.

\begin{tabular}{|c|c|c|c|c|c|c|c|}
\hline \multirow[b]{2}{*}{ Prey Type } & \multicolumn{5}{|c|}{ Attack sequences employed } & \multirow[b]{2}{*}{$\begin{array}{c}\text { Total Prey } \\
\text { captured } \\
(\%)\end{array}$} & \multirow{2}{*}{$\begin{array}{c}\text { Total Prey } \\
\text { not } \\
\text { captured } \\
\text { (\%) }\end{array}$} \\
\hline & $\begin{array}{l}\text { Seize- } \\
\text { Pull out } \\
(\%)\end{array}$ & $\begin{array}{c}\text { Bite- } \\
\text { Pull out } \\
(\%)\end{array}$ & $\begin{array}{c}\text { Bite- } \\
\text { Wrap } \\
(\%) \\
\end{array}$ & $\begin{array}{c}\text { Wrap- } \\
\text { Bite } \\
(\%)\end{array}$ & $\begin{array}{c}\text { Wrap } \\
(\%)\end{array}$ & & \\
\hline Diptera & $\begin{array}{c}12 \\
(40.0)\end{array}$ & $\begin{array}{c}5 \\
(16.7) \\
\end{array}$ & $\begin{array}{c}10 \\
(33.3)\end{array}$ & $\begin{array}{c}3 \\
(10.0)\end{array}$ & $\begin{array}{c}0 \\
(0.0) \\
\end{array}$ & $30(85.7)$ & $5(14.3)$ \\
\hline \multicolumn{8}{|l|}{ Hemiptera } \\
\hline Stink Bugs & $\begin{array}{c}0 \\
(0.0)\end{array}$ & $\begin{array}{c}0 \\
(0.0)\end{array}$ & $\begin{array}{c}8 \\
(42.1)\end{array}$ & $\begin{array}{c}9 \\
(47.4)\end{array}$ & $\begin{array}{c}2 \\
(10.5)\end{array}$ & $19(61.3)$ & $12(38.7)$ \\
\hline Leafhoppers & $\begin{array}{c}1 \\
(50.0)\end{array}$ & $\begin{array}{c}0 \\
(0.0)\end{array}$ & $\begin{array}{c}0 \\
(0.0) \\
\end{array}$ & $\begin{array}{c}1 \\
(50.0)\end{array}$ & $\begin{array}{c}0 \\
(0.0) \\
\end{array}$ & $2(100)$ & $0(0)$ \\
\hline \multicolumn{8}{|l|}{ Hymenoptera } \\
\hline Ants & $\begin{array}{c}1 \\
(3.8)\end{array}$ & $\begin{array}{c}3 \\
(11.5)\end{array}$ & $\begin{array}{c}0 \\
(0.0)\end{array}$ & $\begin{array}{c}18 \\
(69.2)\end{array}$ & $\begin{array}{c}4 \\
(15.4)\end{array}$ & $26(61.9)$ & $16(38.1)$ \\
\hline Winged ants & $\begin{array}{c}0 \\
(0.0)\end{array}$ & $\begin{array}{c}0 \\
(0.0)\end{array}$ & $\begin{array}{c}0 \\
(0.0)\end{array}$ & $\begin{array}{c}3 \\
(100.0)\end{array}$ & $\begin{array}{c}0 \\
(0.0)\end{array}$ & $3(100)$ & $0(0)$ \\
\hline Bees \& Wasps & $\begin{array}{c}0 \\
(0.0)\end{array}$ & $\begin{array}{c}1 \\
(50.0)\end{array}$ & $\begin{array}{c}1 \\
(50.0)\end{array}$ & $\begin{array}{c}0 \\
(0.0) \\
\end{array}$ & $\begin{array}{c}0 \\
(0.0) \\
\end{array}$ & $2(40.0)$ & $3(60.0)$ \\
\hline Lepidoptera & $\begin{array}{c}1 \\
(5.9)\end{array}$ & $\begin{array}{c}0 \\
(0.0)\end{array}$ & $\begin{array}{c}16 \\
(94.1)\end{array}$ & $\begin{array}{c}0 \\
(0.0)\end{array}$ & $\begin{array}{c}0 \\
(0.0)\end{array}$ & $17(68.0)$ & $8(32.0)$ \\
\hline Lepi. Larvae & $\begin{array}{c}0 \\
(0.0) \\
\end{array}$ & $\begin{array}{c}0 \\
(0.0)\end{array}$ & $\begin{array}{c}0 \\
(0.0) \\
\end{array}$ & $\begin{array}{c}2 \\
(100.0)\end{array}$ & $\begin{array}{c}0 \\
(0.0) \\
\end{array}$ & $2(100)$ & $0(0)$ \\
\hline Orthoptera & $\begin{array}{c}0 \\
(0.0)\end{array}$ & $\begin{array}{c}1 \\
(10.0)\end{array}$ & $\begin{array}{c}2 \\
(20.0)\end{array}$ & $\begin{array}{c}7 \\
(20.0)\end{array}$ & $\begin{array}{c}0 \\
(0.0)\end{array}$ & $10(34.5)$ & $18(65.5)$ \\
\hline Odonata & $\begin{array}{c}0 \\
(0.0) \\
\end{array}$ & $\begin{array}{c}0 \\
(0.0) \\
\end{array}$ & $\begin{array}{c}3 \\
(25.0) \\
\end{array}$ & $\begin{array}{c}9 \\
(75.0) \\
\end{array}$ & $\begin{array}{c}0 \\
(0.0) \\
\end{array}$ & $12(80.0)$ & $3(20.0)$ \\
\hline Ephemeroptera & $\begin{array}{c}1 \\
(33.3) \\
\end{array}$ & $\begin{array}{c}1 \\
(33.3)\end{array}$ & $\begin{array}{c}1 \\
(33.3) \\
\end{array}$ & $\begin{array}{c}0 \\
(0.0) \\
\end{array}$ & $\begin{array}{l}0 \\
(0.0) \\
\end{array}$ & $3(100)$ & $0(0)$ \\
\hline Neuroptera & $\begin{array}{c}0 \\
(0.0) \\
\end{array}$ & $\begin{array}{c}1 \\
(100.0)\end{array}$ & $\begin{array}{c}0 \\
(0.0) \\
\end{array}$ & $\begin{array}{c}0 \\
(0.0) \\
\end{array}$ & $\begin{array}{c}0 \\
(0.0) \\
\end{array}$ & $1(100)$ & $0(0)$ \\
\hline $\begin{array}{c}\text { Total } \\
\%\end{array}$ & $\begin{array}{c}16 \\
(12.6)\end{array}$ & $\begin{array}{l}11 \\
(9.4)\end{array}$ & $\begin{array}{c}41 \\
(32.3) \\
\end{array}$ & $\begin{array}{c}51 \\
(40.2)\end{array}$ & $\begin{array}{c}6 \\
(4.7) \\
\end{array}$ & $126(66.0)$ & $65(34.0)$ \\
\hline
\end{tabular}

mobilized exclusively or mainly by wrapping: winged ants, lepidopteran larvae, ants, Odonata and Orthoptera. All the individuals were immobilized by wrapping in winged ants (three individuals) and lepidopteran larvae (two individuals). Ants, Odonata and Orthoptera were also immobilized mainly by wrapping $(84.6 \%, 75.0 \%$ and $70.0 \%$, respectively).

Table 2 shows the attack sequences to living and dead ants. Spiders captured dead ants more successively than living ants $\left(\chi^{2}\right.$-test, $\left.\mathrm{p}<0.05\right)$. Living ants were captured most frequently with WB $(18 / 26=69.2 \%)$. BW was not employed to living ants at all. Spiders captured living ants four times with $\mathrm{W}$, though dead ones were not captured with $\mathrm{W}$ at all. Living ants were more frequently immobilized by wrapping than dead ants $\left(\chi^{2}\right.$-test, $\left.\mathrm{p}<0.01\right)$.

\section{Discussion}

Robinson and his colleagues studied the predatory behavior of spiders of Araneidae such as Nephila clavipes, Micrathena spp., Gasteracantha spp., Argiope argentata, 
Table 2. Frequencies of attack sequences against living and dead ants. Numerals show the numbers of ants. Numerals in parentheses show the percentages.

\begin{tabular}{lccccccc}
\hline \multirow{2}{*}{ Prey Type } & \multicolumn{9}{c}{ Attack sequences employed } & Total Prey & \begin{tabular}{c} 
Total Prey \\
not \\
\cline { 2 - 6 }
\end{tabular} & $\begin{array}{c}\text { Seize- } \\
\text { Pull out } \\
(\%)\end{array}$ & $\begin{array}{c}\text { Bite- } \\
\text { Pull out } \\
(\%)\end{array}$ & $\begin{array}{c}\text { Bite- } \\
\text { Wrap } \\
(\%)\end{array}$ & $\begin{array}{c}\text { Wrap- } \\
\text { Bite } \\
(\%)\end{array}$ & $\begin{array}{c}\text { Wrap } \\
\text { captured } \\
(\%)\end{array}$ & $\begin{array}{c}\text { captured } \\
(\%)\end{array}$ \\
\hline Living ants & 1 & 3 & 0 & 18 & 4 & $26(61.9)$ & $16(38.1)$ \\
& $(3.8)$ & $(11.5)$ & $(0.0)$ & $(69.2)$ & $(15.4)$ & & \\
Dead ants & 2 & 5 & 3 & 6 & 0 & $16(88.9)$ & $2(11.1)$ \\
& $(12.5)$ & $(31.3)$ & $(18.8)$ & $(37.5)$ & $(0.0)$ & & \\
Total & 3 & 8 & 3 & 24 & 4 & $42(71.1)$ & $17(28.8)$ \\
& $(7.1)$ & $(19.0)$ & $(7.1)$ & $(57.1)$ & $(9.5)$ & & \\
\hline
\end{tabular}

Eriophora sp. and Araneus diadematus (Robinson 1969, 1975; Robinson \& Mirick 1971; Robinson et al. 1969; Robinson \& Olazzari 1971; Robinson \& Robinson 1973, 1974, 1976). They presumed three main stages in the evolution of predatory behavior, judging mainly from whether or not attack wrapping was used (Robinson et al. 1969; Robinson 1975). According to them, in the first stage, all the large prey are immobilized by biting (tiny prey are solely seized in the jaws). Seize-pull out and Bite-pull out, are applied to the prey in the stage. In the second stage also, all the large prey are immobilized by biting. Post-immobilization wrapping occurs at the capture site when the prey cannot be pulled from the web in the jaws. Seize-pull out, Bite-pull out and Bite-wrap, are applied in the stage. In the third stage, most large prey are immobilized by wrapping. Seize-pull out, Bite-pull out, Bite-wrap and Wrap-bite, are applied in the stage. Robinson (1975) emphasized that the scheme of the evolution was essentially additive and that new behavioral units and attack sequences were used as alternatives to the old ones in order to extend the range of the prey. For example, attack wrapping (= immobilization wrapping) is thought to be derived from the post-immobilization wrapping at the capture site. Nevertheless, the scheme had to be drawn, depending entirely on the interpretation of the form and the function of predatory behavior, since there was no generally agreed phylogenetic scheme at that time.

There were many opinions on the separation of Araneidae and Tetragnathidae. For example, Kaston (1948) distinguished Tetragnathidae from Araneidae, but included Meta in the latter. On the contrary, Locket et al. (1974) included European metine genera in tetragnathids. Brignoli (1983) regarded Metidae and Tetragnathidae as separate families, but left Nephilinae in Araneidae. Now metine and nephilene genera are included in Tetragnathidae, not in Araneidae (Levi 1986; Coddington \& Levi 1991; Hormiga et al. 1995; Scharff \& Coddington 1997). So, Nephila, whose predatory behavior was regarded as primitive in Araneidae by Robinson (1975), must be included in Tetragnathidae.

There are two types of tetragnathid spiders. One type never immobilizes its prey by wrapping, whereas another type sometimes immobilizes them by wrapping. Nephila $(N$. clavipes, $N$. maculata, $N$. constricta, $N$. truneri, and $N$. clavata), Nephilengys cruentata, Herennia ornatissima and Metleucauge (M. kompirensis, M. yunohamensis, $M$. yaginumai) are included in the former type (Robinson 1975; Robinson \& Mirick 1971; Robinson et al. 1969; Robinson \& Robinson 1973; Yoshida 1989, unpublished data). Though Hormiga et al. (1995) listed Tetragnatha also as a genus without attack wrapping, I observed that $T$. praedonia attacked some types of large prey by wrapping (Yoshida 1987). On the other hand, following tetragnathid species use attack wrap- 
ping: Dolichognatha spp., Leucauge (L. magnifica and other species), Chrysometa spp., Meta (M. reticuloides, M. japonica), and Tetragnatha praedonia (Eberhard 1982; Yoshida 1987, 1990; Yoshida \& Shinkai 1993; this study).

In Nephilinae, all the genera (Nephila, Nephilengys, and Herenia) whose attack behavior was studied, never immobilize the prey by wrapping (Robinson 1975). The species of Nephila feed on fairly large prey as well as small prey (Robinson \& Robinson 1973; Miyashita 1992; Yoshida, unpublished data). The webs of Nephila have large number of radial threads and sticky spirals (Shinkai 1985), and very strong enough to capture large and/or heavy prey (Yoshida, unpublished data). Large and/or dangerous prey such as cicadas, dragonflies, wasps, stink bugs have been observed to be captured by Nephila (Robinson \& Robinson 1973; Yoshida, unpublished data). The high efficiency of the web to capture large and/or dangerous prey may be explained the lack of attack wrapping in this case.

In metine and tertagnathine genera, one type never immobilizes its prey by wrapping, whereas another type sometimes immobilizes them by wrapping. Metleucauge (Yoshida 1989) and some species of Tetragnatha (Hormiga et al. 1995) are included in the former type, though Hormiga et al. (1995) did not state what species of Tetragnatha immobilized its prey only by biting. On the other hand, Dolichognatha, Leucauge, Chrysometa, Meta, and Tetragnatha ( $T$. praedonia) are included in the latter type (Eberhard 1982; Yoshida 1987, 1990; Yoshida \& Shinkai 1993; this study).

Leucauge magnifica, Meta reticuloides, $M$. japonica, and Tetragnatha praedonia immobilized large and/or dangerous prey such as damselflies, winged ants, and millipedes, by wrapping (Yoshida 1987, 1990; Yoshida \& Shinkai 1993; this study). So, attack wrapping may be effective to immobilize such types of prey in tetragnathid spiders as well as araneid spiders. Nevertheless, less silks seem to be used for preyimmobilization by Tetragnathidae than by Araneidae. The whole body of the prey wrapped by Argiope is covered whitely with silks in a short time (Robinson \& Olazarri 1971). On the contrary, it takes a long time for Tetragnatha praedonia and Meta reticuloides to wrap the prey. The silks are so thin that one can see the body of the prey through them (Yoshida 1987, 1990). I have observed that a lady beetle whose whole body had been wrapped with silks by Leucauge magnifica easily escaped from the cocoon of silks (Yoshida, personal observation). These facts may suggest that wrapping is the less effective method for prey-immobilization in Tetragnathidae than in Araneidae. The silks to wrap the prey are pulled from aciniform glands (Kovoor 1987) and tetragnathid spiders have smaller number of aciniform glands than araneid spiders (Coddington 1989; Yoshida 1996, 1999). So, it can be said that the ability of attack wrapping has reduced in Tetragnathidae with the reduction of the number of aciniform glands. It is probably because most metine and tetragnathine spiders specialized to feed on small and/or harmless prey (Yoshida 1987, 1989, unpublished data).

Though Meta and Metleucauge are related genera (Levi 1980), the latter never immobilizes its prey by wrapping (Yoshida 1989). By what manner can the lack of attack wrapping in Metleucauge be explained? It may be related to the prey items. Almost all the prey captured by Metleucauge's webs were mayflies and nematocerous flies. They were small and/or harmless prey which can be immobilized easily by biting. Large and/or dangerous prey such as grasshoppers and wasps were not captured at all (Yoshida 1989). So, the lack of attack wrapping in Metleucauge is probably due that the spider has specialized to feed on mayflies and nematocerous flies.

Since the lack of attack wrapping has been regarded as primitive by Robinson and his colleagues (Robinson 1975; Robinon et al. 1969), Metleucauge as well as Nephila 
may be in the primitive stage of the evolution of predatory behavior. On the contrary, it may be a derived behavioral character. For example, following scenario may be possible: Though the ancestor of Metleucauge had used attack wrapping against large and/or dangerous prey, it lost the ability later because it became to feed on harmless and/or small prey fling above streams. Similarly, Nephila may have lost the ability of attack wrapping because it has made very strong web. Levi (19.78) also regarded the lack of attack wrapping in Micrathena as secondary loss. The method of prey immobilization may be related with the prey items (e.g. Robinson 1975), the number of aciniform glands (Yoshida 1999), the web characteristics (Yoshida, unpublished data). So, the evolution of predatory behavior must be discussed, taking them into consideration.

\section{References}

Brignoli, P. M. 1983. A catalog of the Araneae described between 1940 and 1981. 755pp. Manchester Univ. Press, Manchester.

Coddington, J. A. 1989. Spinnerets silk spigot morphology. Evidence for the monophyly of orbweaving spiders, Cyrtophorinae (Araneidae), and a group Theridiidae-Nesticidae. J. Arachnol., 17: 71-95.

Coddington, J. A. \& Levi, H. W.1991. Systematics and evolution of spiders (Araneae). Annu. Rev. Ecol. Syst., 22: 565-592.

Eberhard, W. G. 1967. Attack behavior of diguetid spiders and the origin of prey wrapping in spiders. Psyche, 74: 173-181.

Eberhard, W. G. 1982. Behavioral characters for the higher classification of orbweaving spiders. Evolution, 36: 1067-1095.

Hormiga, G., Eberhard, W. G. \& Coddington, J. A. 1995. Web-construction behaviour in Australian Phonognatha and the phylogeny of Nephiline and tetragnathid spiders (Araneae: Tetragnathidae). Aust. J. Zool., 43: 313-364.

Kaston, B. J. 1948. Spiders of Connecticut. Bull. State Geol. Natur. Hist. Surv., 70: 1-874.

Kovoor, J. 1987. Comparative structure and histochemistry of silk-producing organs in arachnids. pp. 160-186. In Ecophysiology of spiders (Nentwig, W. ed.) Springer-Verlag, Berlin.

Levi H. W. 1978. The American orb-weaver genera Colphepeira, Micrathena and Gasteracantha north of Mexico (Araneae, Araneidae). Bull. Mus. Comp. Zool., 148: 417-442.

Levi, H. W. 1980. The orb-weaver genus Mecynogea, the subfamily Metinae and the genera Pachgnatha, Glenognatha and Azilia of the subfamily Tetragnathinae north of Mexico (Araneae: Araneidae). Bull. Mus. Comp. Zool., 149: 271-318.

Levi H. W. 1986. The neotropical orb-weaver genera Chrysometa and Homalometa (Araneae: Tetragnathidae). Bull. Mus. Comp. Zool., 151: 91-215.

Locket, G. H., Millidge, A. F. \& Merett, P. 1974. British spiders. Vol. 3. 315pp. Ray Soc. London.

Miyashita, T. 1992. Size composition of prey in the orb-web spider Nephila clavata estimated by video recordings and sight-count censuses. Acta Arachnol., 41: 143-148.

Robinson, M. H. 1969. Predatory behavior of Argiope argentata (Fabricius). Am. Zool., 9: 161-173.

Robinson, M. H. 1975. The evolution of predatory behavior in araneid spiders. pp. 292-312. In Function and Evolution in Behavior (G. Baerends, C. Beer and A. Manning, eds.) Clarendon Press, Oxford.

Robinson, M. H. \& Mirick, H. 1971. The predatory behavior of the golden-web spider Nephila clavipes (Araneae: Araneidaei). Psyche, 78: 123-139.

Robinson, M. H., H. Mirick \& Turner, O. 1969. The predatory behavior of some araneid spiders and the origin of immobilization wrapping. Psyche, 76: 487-501.

Robinson, M. H. \& Olazarri, J. 1971. Units of behavior and complex sequences in the predatory behavior of Argiope argentata (Fabricius)(Araneae: Arachnida). Smith. Cont. Zool., 65: 1-36.

Robinson M. H. \& Robinson, B. 1973. Ecology and behavior of the giant wood spider Nephila maculata (Fabricius) in New Guinea. Smithson. Cont. Zool., 149: 1-76.

Robinson M. H. \& Robinson, B. 1974. The biology of some Argiope species from New Guinea: 
predatory behaviour and stabilimentum construction (Araneae: Araneidae). Zool. J. Linn. Soc., 54: 145-159.

Robinson M. H. \& Robinson, B. 1976. Discrimination between prey types: an innate component of the predatory behavior of araneid spiders. Z. Tierpsychol., 41: 266-276.

Scharff, N. \& Coddington, J. A. 1997. A phylogenetic analysis of the orb-weaving spider family Araneidae (Arachnida, Araneae). Zool. J. Linn. Soc., 120: 355-434.

Shinkai, A. 1985. Comparison in the web structure between Nephila clavata L. Koch and Nephila maculata (Fabricius)(Araneae: Araneidae), and the origin of genus Nephila. Acta Arachnol., 34: 11-22. (in Japanese)

Yoshida, M. 1987. Predatory behavior of Tetragnatha praedonia (Araneae: Tetragnathidae). Acta arachnol., 35: 57-75.

Yoshida, M. 1989. Predatory behavior of three Japanese species of Metleucauge (Araneae: Tetragnathidae). J. Arachnol., 17: 15-25.

Yoshida, M. 1990. Predatory behavior of Meta reticuloides (Araneae: Tetragnathidae). Acta arachnol., 39: 27-38.

Yoshida, M. 1996. Spinnerets and silk spigots in tetragnathid spiders. Bull. Inst. Sci. \& Engineer. 55: 91-106. (in Japanese)

Yoshida, M. 1999. Spinnerets silk spigots morphology of Araneidae, Tetragnathidae, Theridiidae and Linyphiidae (Araneae: Araneoidea). Acta Arachnol., 48: 1-22.

Yoshida, M. \& Shinkai, A. 1993. Predatory behavior and web structure of Meta menardi (Araneae: Tetragnathidae). Acta Arachnol., 42: 21-25.

(Received June 16, 2000/Accepted September 20, 2000) 


\section{Acta Arachnologica, Vol. 49, No. 2 掲載論文の和文要旨}

オオシロカネグモの捕食行動（pp. 117-123）

吉田 真（干525-8577 滋賀県草津市野路東 11-11 立命館大学理工学部生物工学科)

オオシロカネグモの捕食行動を調べた.この 種は餌昆虫に対して, seize-pull out, bite-pull out, bite-wrap, wrap-bite および wrap の 5 つの 捕食行動を示した. 攻撃ラッピングはバッタ, イトトンボ，アリ，カメムシといった大型ある いは危険な餌に対して使用された。また，生き ているアリは死んだアリよりも頻繁にラッピン グで固定された。このことは，攻撃ラッピング が大型あるいは危険な餌の固定に効果的な方法 であることを示唆している。

シロカネグモ属, Mesida 属および Eriovixia 属 (クモ目：アシナガグモ科，コガネグモ科)の円 網種 5 種の台湾からの新記録（pp. 125-131）

卓 逸民 ${ }^{1}$ 谷川明男 ${ }^{2}{ }^{1}$ 中華民國臺灣省臺中市中 港路三段 181 號 東海大學生物系; ${ }^{2}$ 个2480025 神奈川県鎌倉市七里力゙浜東 2-3-1 神奈 川県立七里ガ浜高等学校)

アシナガグモ科の Leucauge argentina (Hasselt 1882), L. tessellata (Thorell 1887), Mesida gemmea Hasselt 1882 の 3 種とコガネグモ科の Eriovixia excelsa（Simon 1889）とサキエダオニ グモ E. sakiedaorum Tanikawa 1999 との 2 種, あわせて 5 種の円網種を台湾新記録種として報 告した.このうちアシナガグモ科の Mesida 属 については台湾新記録属となる. 本論で扱った 5 種について形態的特徵を再記載し, 図示し, これまでのシノニムと既知産地をまとめた。

日本産ヒラタヒメグモ属(クモ目：ヒメグモ科) の 1 新種（pp. 133-135）

吉田 哉（广990-2484 山形市篦田 2 丁目 7 番 16 号)

日本産のヒラタヒメグモ属の 1 新種, Euryopis nigra sp. nov. (クロヒラタヒメグモ, 新 称), を記載した. 本属では日本産として合計 5
種になる。

日本産のツリガネヒメグモ属（クモ目：ヒメグ モ科) のクモ（pp. 137-153）

吉田 哉（干990-2484 山形市篁田 2 丁目 7 番 16 号)

日本よりヒメグモ科ツリガネヒメグモ属のク モ 12 種を記録した.種の検索表および図を付す と共に，本州から琉球列島に分布する Achaear anea ryukyu new species（リュウキュウヒメグ モ一新称一）を新種として記載し，ヨーロッパ に広く分布する A. simulans (Thorell 1875) （ハ モンヒメグモ一新称一) を新記録種として北海 道, 本州東北部から報告した。また, 韓国から 記載された A. ungilensis Kim \& Kim 1996 を $A$. japonica (Bösenberg \& Strand 1906) の新参シノ ニムとした

日本産ヒノマルコモリグモ属（クモ目：コモリ グモ科）の 1 新種（pp. 155-157） 田中穂積 (†661-8520 兵庫県尼崎市南塚口町729-1 園田学園女子大学短期大学部生物教室)

日本（北海道および本州中部）から得られた コモリグモ科ヒノマルコモリグモ属の 1 新種を Tricca yasudai ヤスダコモリグモ（新称）と命名 し記載した。

日本産ケムリグモ属およびホソミトンビグモ属 （クモ目：ワシグモ科）の 3 種（pp. 159-164） 加村隆英（干567-8502 茨木市西安威 2-1-15 追手門学院大学生物学研究室)

日本産ワシグモ科の 3 種を報告した。北海道 産の標本に基づいて，ケムリグモ属の 1 種を Zelotes bifukaensis sp. nov. ビフカケムリグモ (新称) と命名して記載した。また，長野県から 得られた Zelotes kimwha Paik 1986 ミカドケム リグモ（新称）と沖縄県西表島から得られた Aphantaulax seminigra Simon 1878 ヒメトンビ グモ（新称）を日本新記録種として報告した。 